ELORE (ISSN 1456-3010), vol. 18 - 2/2011.

Julkaisija: Suomen Kansantietouden Tutkijain Seura ry.

[http://www.elore.fi/arkisto/2_11/mahlamaki.pdf]

KIRJA-ARVIO

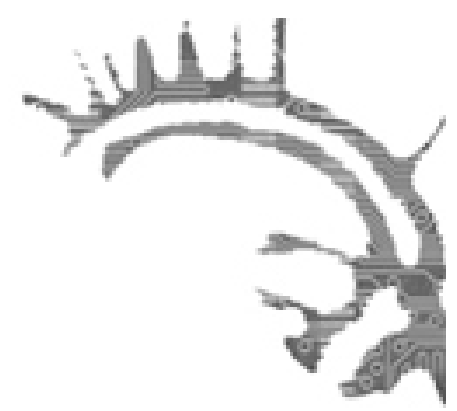

Avaimia ja AVAUKsia KertomuKsien TUTKIMISEEN

HÄGG, SAMULI \& LEHTIMÄKI, MARKKU \& STEINBY, LIISA (toim.) 2009: Näkökulmia kertomuksen tutkimukseen. Helsinki: SKS. 354 sivua.

\title{
Tiina Mahlamäki
}

Narratologia on ollut yksi keskeisimpiä suuntauksia kirjallisuudentutkimuksessa, joka on jakautunut karkeasti ottaen kahteen erilliseen linjaan, formaalis-narratologiseen ja sisällöllis-historialliseen. Nykypäivän tutkimuksessa linjat ovat onnistuneet paikoin myös kohtaamaan. Monien muiden tutkimussuuntausten tavoin myös narratologiassa koettiin 1900-luvun lopulla kerronnallinen käänne klassisesta jälkiklassiseen narratologiaan. Tämän myötä syntyi lukuisia narratologioita, joissa reflektoitiin klassisen narratologian formalistis-strukturalistista - eksaktiin tieteellisyyteen pyrkivää - otetta ja käytettyjä käsitteitä sekä rikottiin sen käyttämiä typologioita ja hierarkioita. Fiktiivisten tekstien muotoon keskittyvästä tutkimuksesta on siirrytty kohti ei-kirjallisia konteksteja huomioonottavaa suuntausta, pohtimaan rakenteiden lisäksi myös sitä, mitä teksti sanoo maailmasta.

Ilman kirjallisuustieteen koulutusta kirjallisuutta tutkivalle narratologiset tutkimustekstit ovat olleet haasteellisia lähestyä. Kulttuurintutkijan on ollut vaikea niitä hyödyntää. Nyt arvioitava artikkelikokoelma Näkökulmia kertomuksen tutkimukseen osoittaa, että narratologian käsitteitä ja menetelmiä voi mainiosti hyödyntää myös perinteen- ja kulttuurintutkimuksessa, tutkittaessa elävien ja eläneiden ihmisten kertomuksia, omaelämäkertoja ja muita muistiaineistoja. Myös kirjallisuudentutkijat ovat avautuneet ottamaan vastaan historian ja kulttuurien tutkimuksen näkökulmia ja teoretisointeja. Tästä yhteistyöstä on muodostunut kiinnostava ja hyödyllinen kokoelma. Kokoelman painopiste on kirjallisuudentutkimuksessa, yleisessä kirjallisuustieteessä, jota on teoksen loppupuolella täydennetty kolmella historian- ja kulttuurintutkimuksen näkökulmia avaavilla artikkeleilla. Mutta käsitteet, joita teoksen artikkeleissa avataan ja tarkastellaan, ovat tuttuja ja tärkeitä sekä kirjallisuuden että kulttuurintutkijalle. Tällaisina voidaan mainita vaikkapa kertomus, fiktiivisyys, aika ja paikka, subjekti sekä narratiivisuus. Tarkastelen tätä teosta nimenomaan kulttuurintutkijan näkökulmasta. 


\section{KLASSISEN JA JÄLKIKLASSISEN RAJAPINNOILLA}

Teoksen avaava Markku Lehtimäen artikkeli valottaa narratologian suuntauksia ja kehitystä. Tarkastelun kohteena narratologiassa on tekstin rakenne, ei tekstin tulkinta, kuten kulttuurintutkijoilla useimmiten - vaikka on totta kai selvää, että tekstin rakenteellakin on merkitystä. Jos kulttuurintutkijan mielestä narratologian tarjoama kirjallisuuden lukutapa vaikuttaa keinotekoiselta, hän on oikeassa, mutta lukutavan keinotekoisuus ja "luonnottomuus" on tarkoituksellista ja siksikin ulkopuoliselle, narratologiaan perehtymättömälle lukijalle vaikeasti avautuvaa. Narratologisen tutkimuksen ei välttämättä ole tarkoituskaan avautua ulkopuoliselle, sillä se on usein hyvin sisäänpäin lämpiävää, metanarratologiaa, jolloin keskustelun aiheena on itse narratologia, siinä käytetyt mallit, analyyttiset välineet ja niiden selitysvoimaisuus.

Keskittyminen kirjallisuudellisuuteen tai kirjallisuudellisuuksiin vie lukijan pois tekstin merkityksistä, tulkinnoista ja konteksteista kohdistaessaan katseensa teksteissä toteutettuihin keinoihin. Kuten Samuli Häggin artikkeli venäläisestä formalismista osoittaa, kyse on pyrkimyksestä abstraktiin tutkimukseen, halusta täyttää tieteellisyyden vaatimukset. Vaikka venäläisten formalistien pyrkimyksiä ei näkisikään mielekkäinä, oli formalisteilla kuitenkin kunnianhimoiset pyrkimykset toteuttaa historiallista näkökulmaa, joka sidotaan kulttuuristen ja sosiaalisten järjestelmien vuorovaikutukseen (vaikka he eivät siinä täysin onnistuneetkaan). Sekä Lehtimäki että Hägg esittelevät artikkeleissaan kiinnostavalla tavalla erottelua klassiseen ja jälkiklassiseen narratologiaan sekä niiden ominaispiirteitä ja suuntauksia. Osion artikkeleissa (oikeastaan koko teoksen artikkeleissa) etsitään ja löydetään rajapintoja ja kosketuskohtia narratologisen ja muun humanistisen tutkimuksen välillä.

Liisa Steinbyn tarkastelun kohteena ovat ajan, paikan ja subjektin käsitteet Gérad Genetten strukturalistisessa narratologiassa. Hän ei niiinkään esittele Genetten näkemyksiä, vaan käyttää tätä esimerkkitapauksena siitä, miten klassisen strukturalismin ajattelutapa toimii. Maria Mäkelän artikkeli taas keskittyy kognitiiviseen narratologiaan, jonka keskiössä on "kokeva ja kokemustaan järjestävä - kerronnallistava - ihmismieli" (s. 111). Kiinnostava ulottuvuus tässä on se, että tutkittava ihmismieli on nimenomaan fiktiivinen - kysytään, miten kertomakirjallisuus kykenee valottamaan käsityksiä ihmismielestä. Pekka Tammen artikkelissa taas tartutaan kertomuksen vaeltavaan ja eri tieteenaloille laventuneeseen käsitteeseen. Ovatko kertomuksen käsitteen määrittelyt laventuneet jo liikaakin? Ja mitä siitä on seurannut? Kertomusteoreettisia määritelmiä valotetaan Anton Tšehovin novellin avulla.

\section{KLASSISEN JA JÄLKIKLASSISEN RAJAPINNOILLA}

Teoksen ensimmäisen osan artikkeleissa pohditaan siis klassisen ja uuden (jälki) klassisen narratologian rajoja, eroja ja mahdollisuuksia. Sellaisena se toimii hyvänä johdatuksena aiheeseen. Teoksen toisessa osassa (jälkiklassisessa) pohditaan kertomusten rakenteiden sijaan niiden funktioita. Liisa Steinbyn artikkelissa tarkastellaan 
Tiina Mahlamäki: Avaimia ja avauksia kertomuksien tutkimiseen

venäläisen kirjallisuuden tutkijan ja filosofin Mihail Bahtinin keskeisiä käsitteitä. Erityisen huomion kohteeksi Steinby nostaa sen, että Bahtinin käyttämät käsitteet eivät olleet uusia ja historiattomia, vaan niiden muotoutumisen ja sisällön taustalta voi löytyä niin uuskantilaista (Ernst Cassirer), hegeliläistä kuin Georg Lukácsinkin ajattelua. Moni olettaa käsitteet nimenomaan Bahtinin oman ja omaperäisen ajattelun tuloksiksi, sillä Bahtin ei syystä tai toisesta asettanut ajatteluaan osaksi historiallista jatkumoa - hän ei siis viittaa muihin. Steinby keskittyy artikkelissaan erityisesti kronotoopin käsitteeseen, joka ei siis missään nimessä ole rajattu ja tarkasti märieltelävissä oleva käsite vaan hyvin epämääräinen. Narratologiseen tutkimukseen käsitettä on siis vaikea soveltaa, mutta kulttuurintutkimukseen käsite epämääräisyydessään käy mainiosti, sillä se sisältää myös ja erityisesti maailmankuvallisia elementtejä. Bahtinin käsitteet - kronotoopin lisäksi esimerkiksi dialogisuus, groteski, parodia - ovat taas 1970-luvun Bahtin-boomin aiheuttaman kyllääntymisen jälkeen nousseet taas salonkikelpoisiksi ja niitä on onnistuneesti sovellettu useissa viimeaikaisissa tutkimuksissa.

Hanna Meretoja ottaa artikkelissaan tarkastelunsa kohteeksi narratiivisen käänteen, ajatuksen siitä, että yhä useammalla tieteenalalla on otettu lähtökohdaksi se, että "inhimillinen kokemustodellisuus on luonteeltaan perustavalla tavalla narratiivista" (s. 207). Keskeinen kysymys, johon Meretoja artikkelissaan paneutuu, on kiista siitä, miten kertomuksen ja inhimillisen todellisuuden välinen suhde olisi mahdollista ymmärtää - narratiivisuuden epistemologia ja ontologia. Liisa Steinbyn kolmannessa artikkelissa tarkastellaan narratologian kognitiivista käännettä sekä sitä, miten kognitiivinen narratologia suhtautuu yhteen kirjallisuushistorian keskeiseen kysymykseen: mikä on kertomuksen tiedollinen arvo - miten kirjallisuuden välittämä tieto on suhteessa tieteen antamiin vastauksiin? Kysymys saa erilaisen muodon ja erilaisia vastauksia kirjallisuushistorian eri vaiheissa.

\section{KLASSISEN JA JÄLKIKLASSISEN RAJAPINNOILLA}

Kulttuurintutkijalle teoksen viimeiset osan artikkelit tarjoavat tutumpia lähestymistapoja, joskaan niiden sisältö ja lähestymistavat eivät ole välttämättä uusia ja yllättäviä. Päivi Kosonen tarkastelee modernia omaelämäkertaa kertomuksena. Kronologia tai kausaalisuus eivät ole modernin omaelämäkerran keskeisiä ominaisuuksia. Kyse on pikemmin identiteetin ja elämän kokonaismerkityksen rakentamisen logiikasta. Vaikka lukija olettaa omaelämäkerran kirjoittajan kertovan todenmukaisesti elämänsä kulusta, tapahtumien paikkansapitävyys ei välttämättä ole lukijan tarkastettavissa, eikä sillä ole merkitystäkään, sillä "omaelämäkerran tositapahtumallisuus on näet erilaatuista kuin historiankirjoituksen" (s. 287). Omaelämäkerran todellisuus on subjektiivista - unia, ajatuksia ja muistikuvia, kuten C. G. Jungin tunnetussa omaelämäkerrassa. Tämän vuoksi omaelämäkertoja tulisikin tarkastella nimenomaan "kertomuksena: tekstinä, tarinana ja diskurssina" (s. 291). Jorma Kalela taas puolestaan vastaa artikkelissaan kysymykseen, "Miksi ei pidä ajatella, että historiantutkija tuottaa kertomuksia?" Hän muistuttaa tärkeästä erosta historiankirjoituksen ja historiantutkimuksen välillä. Historiantutkijan on tuotettava kestävää tietoa, mutta sen on myös oltava yleisön 
kannalta merkittävää. Kalela esittää vaatimuksia historiantutkimukselle: tutkijan on "esiteltävä monimutkainen päätelmärakenne, joka perustelee tulokset", lisäksi hänen on vakuutettava yleisö viestinsä tärkeydestä. Tämä ei kuitenkaan vielä riitä, sillä tutkijan on myös herätettävä lukijoiden historiankiinnostus ja houkuteltava heidät dialogiin ja tuottamaan oman panoksensa keskusteluun.

Kokoelman viimeisessä artikkelissa Jyrki Pöysä palaa alun narratologisen osion esittelemään aihepiiriin, mutta uudesta näkökulmasta. Hän kohdentaa katseensa toimijuuteen ja sen rakentumiseen kertomuksissa. Toimijuuden käsite onkin tämänhetkisessä (erityisesti sukupuolen merkitystä tarkastelevassa) kulttuurintutkimuksessa ajankohtainen ja pohdittu. Samaan keskustelukenttään asettuu myös Pöysän artikkeli, joka jatkaa positiointiteorian sovelluksia - positiointi ja subjektipositio ovat kaikille keskustelua seuranneille tuttuja. Kun tämä näkökulma yhdistetään narratologiaan, nähdään, että nimenomaan kertomukset toimivat positioiden muokkaamisen välineinä ja toimijuuden tuottamisen keinoina. Pöysä haastaakin soveltamaan tätä ja muita narratologian lähestymistapoja erilaisiin "pieniin kirjallisuuksiin", kuten vaikkapa kirjoituskilpailujen elämäkerrallisiin teksteihin.

Kertomusten tutkiminen yhdistää monia tieteenaloja, joskin kirjallisuudentutkimus on kehittänyt siihen aivan omanlaisensa tutkimussuuntauksen, narratologian. Näkökulmia kertomuksen tutkimukseen on hyvä johdatus siihen, miten monilla tavoin kertomusta voidaan lähestyä ja siihen, miten eri tutkimussuuntausten ja tieteenalojen edustajat voivat hyötyä ja hyödyttää toisiaan. Teoksen painopiste on narratologian ja sen suuntausten esittelyssä, mutta kirjan loppupuolen artikkelit tarjoavat myös muita, kulttuurintutkimuksellisia lähestymistapoja kertomuksiin.

Filosofian tohtori Tiina Mahlamäki on uskontotieteen yliopisto-opettaja Turun yliopiston historian, taiteen ja kulttuurin tutkimuksen laitoksella. 